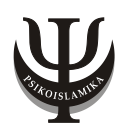

\title{
Stres Kerja Ditinjau dari Konflik Peran Ganda dan Dukungan Sosial pada Perawat
}

\begin{abstract}
ABSTRAK Penelitian ini bertujuan untuk mengetahui hubungan skonflik peran ganda dan dukungan sosial dengan stres kerja pada perawat. Subjek penelitian ini adalah 120 perawat salah satu rumah sakit swasta di Yogyakarta yang bekerja pada ruang inap. Teknik pengambilan sampel menggunakan non random secara purposive. Metode dan alat pengumpulan data penelitian ini menggunakan wawancara semi terstruktur, angket dan skala. Analisa data menggunakan uji regresi ganda (multiple regression) dengan metode enter. Hasil pengolahan data diperoleh nilai $\mathrm{R}=0,633 ; \mathrm{R}^{2}$ $=0,400 ; \mathrm{F}=39,050 ; \mathrm{p}=0,000(\mathrm{p}<0,05)$, menunjukkan ada hubungan yang signifikan antara konflik peran ganda dan dukungan sosial dengan stres kerja. Nilai koefisien determinasi $\left(R^{2}\right)=0,400$ menunjukkan sumbangan efektif konflik peran ganda dan dukungan sosial terhadap stres kerja sebesar $40 \%$ dan sisanya $60 \%$ dipengaruhi variabel lain yang tidak menjadi fokus penelitian ini.
\end{abstract}

\section{Ummu Hany Almasitoh}

Dosen Universitas Widya Dharma Klaten, Fakultas Psikologi

Jl. Ki Hajar Dewantara, Klaten Utara No. 168, Klaten 57401

Email:mawar_4lhany@yahoo.co.id

PSIKOISLAMIKA, Jurnal Psikglogidslam (JPI) Copyright @ 2011 Lembaga Penelitian Pengembangan dan Keislaman (LP3K). Vol 8 No.1 2011 63-82 


\section{Muqadimah}

Pelayanan kesehatan termasuk industri jasa kesehatan yang utama, setiap rumah sakit bertanggung jawab terhadap penerimaan jasa pelayanan kesehatan. Baik buruknya kinerja organisasi dapat diukur dari kinerja medis dan non medis dalam memberikan pelayanan pada pasien. Setiap hari, dalam melaksanakan pengabdiannya seorang perawat tidak hanya berhubungan dengan pasiennya, tetapi juga dengan keluarga pasien, teman pasien, rekan kerja sesama perawat, berhubungan dengan dokter dan perawat, peraturan yang ada di tempat bekerja, beban kerja yang kadangkala dinilai tidak sesuai dengan kondisi fisik, psikis dan emosionalnya.

Ellis dan Harley (dalam Pratopo, 2001) mendefinisikan perawat adalah orang yang merawat, memelihara, dan menjaga orang yang membutuhkan karena sakit. Situs wikipedia mendefinisikan perawat sebagai tenaga profesional di bidang perawatan kesehatan yang terlibat dalam kegiatan perawatan. Perawat juga dapat terlihat dalam riset medis dalam berbagai jenis perawatan serta menjalankan beragam fungsi non klinis yang diperlukan untuk perawatan kesehatan (http://id.wikipedia.org/wiki/perawat). Gunarsa (1995) menjelaskan perawat adalah individu yang telah dipersiapkan melalui pendidikan untuk turut serta merawat dan menyembuhkan orang yang sakit yang dilaksanakan sendiri atau di bawah pengawasan supervisi dokter atau penyelia.

Berdasarkan wawancara dengan dua orang perawat salah satu rumah sakit swasta di Yogyakarta pada tanggal 28-29 November 2010, tugas-tugas pokok perawat pelaksanaan bagian rawat inap antara lain yaitu melaksanakan pengkajian perawatan, melaksanakan analisis data untuk merumuskan diagnosis keperawatan, merencanakan dan melaksanakan evaluasi keperawatan sederhana pada individu, melaksanakan pendokumentasian askep, melaksanakan sistem kerja yang terbagi atas tiga waktu yaitu pukul 06.30-13.30, pukul 13.30-20.30 dan pukul 20.30-06.30, melaksanakan tugas siaga on call di rumah sakit, memelihara peralatan keperawatan dan medis agar selalu dalam keadaaan siap pakai, melakukan pre serta post conference dan serah terima pasien pada saat pergantian dinas, mengikuti pertemuan berkala yang diadakan oleh kepala ruang, dan melakukan droping pasien. Tugas-tugas yang begitu banyak serta monoton menjadi stresor bagi perawat, terkadang perawat juga harus berhadapan dengan sikap pasien yan r amosional. 
Selain permasalahan yang dihadapi tersebut, proses kerja yang membosankan dan sikap pasien yang emosional, permasalahan yang menimbulkan stres kerja perawat adalah keterbatasan SDM dan peran sebagai wanita bekerja untuk memenuhi kebutuhan keluarga dan sebagai ibu rumah tangga yang sama-sama membutuhkan waktu, tenaga, dan perhatian.

Menurut Swedarma (dalam Fitria, 2006) kurangnya kapasitas perawat dibandingkan jumlah pasien menyebabkan perawat akan mengalami kelelahan dalam bekerja karena kebutuhan pasien terhadap asuhan keperawatan lebih besar dari standar kemampuan perawat. Hal tersebut dibenarkan dengan hasil penelitian Jamal (dalam Miner, 1992) dan juga Ree dan Cooper (dalam Suryanita, 2001) yang menyatakan bahwa perawat memiliki tingkat stres yang lebih tinggi dibanding dengan anggota medis lainnya.

Stres kerja merupakan beban kerja yang berlebihan, perasaan susah dan ketegangan emosional yang menghambat performance individu (Robbins, 2004). Menurut Sheridan dan Radmacher (1992) serta Gibson, Ivancevich, dan Donnely (1994), stres kerja dipengaruhi oleh kondisi organisasi, seperti penetapan arah dan kebijaksanaan organisasi, perubahan strategi organisasi, dan keuangan, tuntutan kerja, tanggung jawab atas orang lain, perubahan waktu kerja, hubungan yang kurang baik antar kelompok kerja dan konflik peran. Akibatnya konsentrasi kerja terganggu, kinerja kurang memuaskan dan individu tidak dapat memenuhi tuntutan pekerjaannya karena kurangnya dukungan sosial (Luthans, 1998).

Dalam kenyataannya, kebanyakan perawat di indonesia adalah wanita. Peran ganda yang diemban oleh wanita ini sangat riskan dengan konflik keluarga-pekerjaan. Konflik dalam keluarga sangat berpengaruh dengan perilaku kerja dan kinerja seseorang (Sastrohadiwiryo, 2003). Konflik-konflik tersebut akan menghambat proses pelaksanaan suatu pekerjaan. Apalagi pada wanita yang bekerja, karena konflik yang dihadapi dapat menyebabkan seseorang tidak dapat berfungsi secara normal dan menjadi tidak seimbang (Mansfield, Koch, Henderson, Vicary, Cohen, \& Young, 1991).

Hasil penelitian yang dilakukan oleh Cinnamon dan Rich (2002), menunjukkan ibu yang bekerja ternyata lebih sering mengalami konflik dan permasalahan serta lebih menekankan pentingnya permasalahan keluarga dibandingkan pekerjaan, ketika keluarga sebagai domain yang paling penting bagi kebanyakan wanita. 
Selanjutnya hasil penelitian yang dilakukan Suriyasam (dalam Budiman, 2006) menunjukkan bahwa faktor penting yang dapat mengurangi dilema antara keluarga dan pekerjaan bagi wanita adalah adanya dukungan dari suami. Sekaran (1986) mengatakan bahwa dukungan dan bantuan yang diberikan suami dan anggota keluarga lainnya akan memberikan kesempatan kepada istri untuk mengembangkan karirnya. Adanya dukungan sosial dari anggota keluarga ini akan memberikan rasa aman bagi wanita untuk berkarir.

Rook (1987) mengatakan dukungan yang diberikan kepada orang-orang yang mengalami banyak tekanan dalam pekerjaan dapat berupa dukungan instrumen, nasehat dan emosi. Hasil penelitian Newsom dan Schultz (1996) menemukan bahwa kelemahan fisik seseorang dikaitkan dengan sedikitnya dukungan keluarga, dukungan rekan kerja dan berkurangnya perasaan saling memiliki dan tidak adanya dukungan meterial dari orang lain.

Dukungan sosial dari tempat kerja dapat memberikan kontribusi, terutama pada produktivitas dan kesejahteraan karyawan (Hodson, 1997). Ganster, Fusilier, dan Mayes (1986) mengatakan bahwa dukungan sosial rekan kerja berhubungan secara langsung integrasi seseorang pada lingkungan sosial di tempat kerjanya. Rekan kerja yang mendukung menciptakan situasi tolong menolong, bersahabat, dan bekerja sama akan menciptakan lingkungan kerja yang menyenangkan serta menimbulkan kepuasan dalam bekerja (Hadipranata, 1999).

Hal tersebut sesuai dengan penelitian French (dalam Katz \& Kahn, 1978) dan Tellenback, Breuner, Sten-Olof, dan Lofgren (1983) menemukan bahwa dukungan sosial dapat mencegah terjadinya psychological distress di lingkungan kerja.

Berdasarkan fenomena di atas, penulis berminat untuk melakukan suatu penelitian mengenai "stres kerja ditinjau dari konflik peran ganda dan dukungan sosial pada perawat."

\section{Kerangka Kerja Teoritik}

Stres Kerja

Menurut Riggio (2003) stres kerja sebagai reaksi fisiologis dan atau psikologis terhadap suatu kejadian yang dipersepsi individu sebagai ancaman. Evan dân johthisbon (2000) menyebutkan bahwa stres 
kerja merupakan satu faktor yang menentukan naik turunnya kinerja karyawan. Penelitian ini juga didukung Luthans (1998) bahwa pemicu stres kerja tersebut berasal dari interaksi seseorang dengan pekerjaan dan lingkungan kerjanya yang tidak nyaman. Stres kerja menyebabkan penyimpangan pada fungsi psikologis, fisik dan tingkah laku individu yang menyebabkan terjadinya penyimpangan dari fungsi normal (Beehr \& Newman, 1988; dan Robbins 2004). Sementara Beehr (1985) menyebutkan bahwa gangguan psikologis yang paling sering terjadi sebagai akibat stres kerja adalah kecemasan dan depresi.

Menurut Sheridan dan Radmacher (1992), ada tiga faktor penyebab stres kerja, yaitu yang berkaitan dengan lingkungan, organisasi, dan individu yang diuraikan sebagai berikut:

1. Faktor lingkungan, yaitu keadaan secara global. Lingkungan yang dapat menyebabkan stres ialah ketidakpastian lingkungan, seperti ketidakpastian situasi ekonomi, ketidakpastian politik, dan perubahan teknologi. Kondisi organisasi ini akan mempengaruhi individu yang terlibat di dalamnya (Sheridan \& Radmacher, 1992).

2. Faktor organisasional, yaitu kondisi organisasi yang langsung mempengaruhi kinerja individu. Kondisi-kondisi tersebut dapat dikategorikan sebagai berikut:

a) Karakteristik intrinsik dalam pekerjaan, yaitu setiap pekerjaan memiliki kondisi yang berkaitan dengan pekerjaan. itu sendiri. Karakteristik intrinsik tersebut antara lain berupa (1) tuntutan kerja (task demands), seperti disain kerja, otonomi, keragaman tugas, tingkat otomatisasi (Sheridan \& Radmacher, 1992), otoritas bertingkat ganda (multilevel of authority), heterogenitas personalia, saling ketergantungan dalam pelaksanaan tugas, dan spesialisasi (Schultz, 1982) dan juga (2) beban kerja yang berupa satuan tugas atau pekerjaan yang harus diselesaikan dalam satuan waktu tertentu. Tugas yang berlebihan (work overload) dan sebaliknya, beban kerja yang terlalu ringan pun dapat menyebabkan stres sama besarnya (Gibson, dkk., 1994).

b) Karakteristik peran individu. Pekerjaan atau jabatan yang disandang individu memunculkan peran. Hal ini merupakan norma-norma sesial yang harus dituruti individu menurut posisinya dalam nekerjaan (RiggißP1996). Karakteristik. 
yang berhubungan dengan peran, antara lain: (1) konflik peran, muncul ketika terjadi ketidakseimbangan antara tugas dan standar, atau nilai-nilai pada diri individu dan atau keluarganya (Schultz, 1982; Beutell \& Greenhauss, 1983; Luthans, 1998). (2) ketidakjelasan peran, muncul ketika individu tidak memahami dengan jelas ruang lingkup, tanggung jawab, atau apa yang diharapkan dalam melaksanakan tugas. (3) beban peran, berhubungan dengan tuntutan peran yang terlalu tinggi atau terlalu rendah bagi kedudukan dalam jabatan (Anaroga, 1992). (4) ketiadaan kontrol, terjadi ketika individu merasa tidak mempunyai kontrol atas lingkungan kerja atau sikapnya sendiri dalam bekerja (Riggio, 1996).

c) Karakteristik lingkungan sosial. Komposisi personalia dalam organisasi akan membentuk pola hubungan interpersonal. Kondisi sosial yang menjadi sumber stres terjadi pada bentuk pola hubungan antar rekan kerja, atasan dengan bawahan, dan dengan klien dengan konsumen (Fontana, 1993). Hubungan yang kurang baik antar kelompok kerja akan mempengaruhi kesehatan dan kesejahteraan individu dan organisasi (Gibson, dkk., 1994).

d) Iklim organisasi, yaitu yaitu karakteristik khas yang bersifat relatif tetap dari lingkungan suatu organisasi yang membedakannya dengan organisasi lainnya. Iklim organisasi meliputi sistem penggajian, disiplin kerja dan proses pengambilan keputusan (Sheridan \& Radmacher, 1992); budaya kerja yang mencakup rasa memiliki, konsultasi, dan komunikasi (Gibson, dkk., 1994).

e) Karakteristik fisik lingkungan kerja. Kondisi fisik lingkungan suatu pekerjaan memiliki pengaruh penting pada kinerja dan kepuasan kerja (Gifford, 1987). Beberapa kondisi fisik dapat mempengaruhi kemunculan stres, seperti polusi bahan kimia, penggunaaan asbes, polusi asap rokok, batu bara, dan kebisingan (Napoli, Kilbride, \& Tebs 1988).

3. Faktor individual, terdapat dalam kehidupan pribadi individu di luar pekerjaan, seperti masalah keluarga dan ekonomi (Sheridan \& Radmacher, 1992).

\section{croated with




\section{Aspek-aspek Stres Kerja}

Menurut Schultz dan Schultz (1994) dan Robbins (2004), aspek-aspek stres kerja meliputi, pertama deviasi fisiologis, hal ini dapat dilihat pada orang yang terkena stres antara lain adalah sakit kepala, pusing, pening, tidak tidur teratur, susah tidur, bangun terlalu awal, sakit punggung, susah buang air besar, gatal-gatal pada kulit, tegang, pencernaan terganggu, tekanan darah naik, serangan jantung, keringat berlebihan, selera makan berubah, lelah atau kehilangan daya energi, dan lain-lain. Kedua adalah deviasi psikologis yang mencakup sedih, depresi, mudah menangis, hati merana, mudah marah, dan panas, gelisah, cemas, rasa harga diri menurun, merasa tidak aman, terlalu peka, mudah tersinggung, marah-marah, mudah menyerang, bermusuhan dengan orang lain, tegang, bingung, meredam perasaan, komunikasi tidak efektif, mengurung diri, mengasingkan diri, kebosanan, ketidakpastian kerja, lelah mental, kehilangan spontanitas dan kreativitas, dan kehilangan semangat hidup. Serta yang ketiga adalah deviasi perilaku yang mencakup kehilangan kepercayaan kepada orang lain, mudah mempersalahkan orang lain, mudah membatalkan janji atau tidak memenuhi janji, suka mencari kesalahan orang lain atau menyerang orang lain, terlalu membentengi atau mempertahankan diri, meningkatnya frekuensi absensi, meningkatkan penggunaan minuman keras dan mabuk, sabotase, meningkatnya agresivitas dan kriminalitas.

\section{Jenis-Jenis Stres Kerja}

Quick dan Quick (1984) mengkategorikan jenis stres menjadi dua, yaitu: (1) Eustress, adalah akibat positif yang ditimbulkan oleh stresyangberupa timbulnya rasa gembira, perasaanbangga, menerima sebagai tantangan, merasa cakap dan mampu, meningkatnya motivasi untuk berprestasi, semangat kerja tinggi, produktivitas tinggi, timbul harapan untuk dapat memenuhi tuntutan pekerjaan, serta meningkatnya kreativitas dalam situasi kompetitif. (2) Distress, adalah akibat negatif yang merugikan dari stres, misalnya perasaan bosan, frustrasi, kecewa, kelelahan fisik, gangguan tidur, mudah marah, sering melakukan kesalahan dalam pekerjaan, timbul sikap keragu-raguan, menurunnya motivasi, meningkatnya absensi, serta timbulnya sikap apatis.

\section{Created with}




\section{Konflik Peran Ganda}

Menurut Kahn (dalam Duxbury \& Higgins, 1991) adalah bentuk dari inter-role-conflict dimana tekanan peran dari pekerjaan dan lingkungan keluarga satu sama lain saling bertentangan. Greenhauss dan Beutell (dalam Voydanoff, 1988) menyatakan konflik peran ganda merupakan bentuk dari interrole conflict, peran pekerjaan dan keluarga membutuhkan perhatian yang sama. Lebih lanjut Beutell dan Greenhauss (1985) mengatakan bahwa seseorang dikatakan mengalami konflik peran ganda apabila merasakan suatu ketegangan dalam menjalani peran pekerjaan dan keluarga.

Parasuraman, Greenhauss, dan Granrose (1992) dan Voydanoff (1995), mengemukakan bahwa konflik peran ganda dapat terjadi dalam tiga jenis, yang pertama adalah konflik yang disebabkan waktu (time-based conflict), yaitu ketika waktu yang dimiliki individu digunakan untuk memenuhi satu peran tertentu sehingga menimbulkan kesulitan untuk memenuhi satu peran tertentu sehingga menimbulkan kesulitan untuk memenuhi perannya yang lain. Kedua adalah konflik yang disebabkan oleh ketegangan (strainbased conflict), yaitu yang dialami ketika ketegangan-ketegangan yang dihasilkan oleh suatu peran mengganggu peran yang lain. Dan yang ketiga adalah konflik yang disebabkan oleh perilaku (behaviour-based conflict), yaitu konflik yang disebabkan karena kesulitan perubahan perilaku dari satu peran ke peran lain. Misalnya, sebagai seorang manajer dituntut untuk bersikap agresif dan obyektif, namun sebagai ibu di rumah harus berubah perilaku menjadi seorang yang hangat (afektif).

Menurut Sekaran (1986) ada beberapa hal yang menyebabkan terjadinya konflik peran ganda, yaitu pengasuhan anak dan bantuan pekerjaan rumah tangga, komunikasi dan interaksi dengan keluarga, waktu untuk keluarga, penentuan prioritas sebagai seorang istri, dan tekanan karir dan keluarga (Spitze dalam Gelles, 1995).

\section{Dukungan Sosial}

Dukungan sosial merupakan suatu kebersamaan sosial, dimana individu berada di dalamnya, yang memberikan beberapa dukungan seperti bantuan nyata, dukungan informasi, dan dukungan emosional sehingga individu merasa nyaman (Lazarus, 1991). Dukungan sosiarejugg "therupakan suatu kumpulan proses 
sosial, emosional, kognitif, dan perilaku yang terjadi dalam hubungan pribadi, dimana individu merasa mendapat bantuan dalam melakukan penyesuaian atas masalah yang dihadapi (Dalton, Elias, \& Wardersman, 2001).

Menurut Cohen dan Syme (1985), terdapat empat aspek dukungan sosial, yaitu (1) dukungan emosional, seperti empati, cinta, dan kepercayaan yang di dalamnya terdapat pengertian, rasa percaya, penghargaan dan keterbukaan. (2) dukungan informatif, berupa informasi, nasehat, dan petunjuk yang diberikan untuk menambah pengetahuan seseorang dalam mencari jalan keluar pemecahan masalah. (3) dukungan instrumental, seperti penyediaan sarana yang dapat mempermudah tujuan yang ingin dicapai dalam bentuk materi, pemberian kesempatan waktu, pekerjaan, peluang serta modifikasi lingkungan. Dan (4) penilaian positif, berupa pemberian penghargaan atas usaha yang telah dilakukan, memberi umpan balik mengenai hasil atau prestasi, penghargaan dan kritik yang membangun.

Lingkungan sosial berpotensi untuk memberikan dukungan sosial bagi individu. Dukungan sosial dapat diperoleh dari orang lain yang ada di sekitar individu, misalnya pasangan, keluarga, teman dan sahabat, tetangga, rekan kerja, serta individu masyarakat lainnya (Thoits, 1986; Sarafino, 1994). Menurut Quick dan Quick (1984), dukungan sosial dapat bersumber dari jaringan sosial yang dimiliki oleh individu yaitu dari lingkungan pekerjaan (atasan, rekan kerja, bawahan), lingkungan keluarga (pasangan, anak, saudara).

Menurut Cassel dan Cob (dalam Norris \& Kaniasty, 1996) mengemukakan dukungan yang dirasakan secara lebih konsisten mampu meningkatkan kesehatan psikis dan melindungi psikis dalam kondisi stres. Johnson dan Johnson (2000) mengungkapkan bahwa dukungan sosial secara umum akan meningkatkan (1) produktivitas, melalui penngkatan motivasi, kualitas penalaran, kepuasan kerja dan mengurangi dampak stres kerja. (2) kesejahteraan psikologi dan kemampuan penyesuaian diri melalui perasaan memiliki, kejelasan identitas diri, harga diri, pencegahan neurotisme dan psikopatologi, pengurangan distres, dan penyediaan sumber yang dibutuhkan. (3) kesehatan fisik dan (4) manajemen stres yang produktif melalui perhatian, informasi, dan umpan balik yang diperlukan untuk melakukan penangananderhadap stres. 


\section{Metode}

Penelitian ini dilakukan pada tanggal 3-7 Januari 2011 sebanyak 120 perawat salah satu rumah sakit swasta di Yogyakarta yang bekerja pada ruang inap. Teknik pengambilan sampel menggunakan non random secara purposive. Metode dan alat pengumpulan data penelitian ini menggunakan wawancara semi terstruktur, angket dan skala.

Untuk menganalisis data dalam penelitian ini digunakan uji regresi ganda (multiple regression) dengan metode enter untuk mengetahui hubungan antara konflik peran ganda dan dukungan sosial dengan stres kerja. Sebelum dilakukan uji hipotesis, terlebih dahulu dilakukan uji asumsi, yaitu uji normalitas sebaran dan uji linieritas. Hasil pengujian hipotesis dengan komputerisasi melalui bantuan program SPSS menggunakan taraf signifikansi $\mathrm{p}<0,05$.

\section{Hasil}

Uji normalitas sebaran menghasilkan sebaran variabel stres kerja diperoleh nilai K-S sebesar 1,161 dengan $\mathrm{p}=0,135$, nilai K-S sebesar 0,858 dengan $\mathrm{p}=0,453$ untuk variabel konflik peran ganda, dan nilai K-S sebesar 1,264 dengan $p=0,082$ untuk variabel nilai dukungan sosial. Berdasarkan hasil ini, maka dapat disimpulkan bahwa sebaran skor dari ketiga variabel adalah normal. Uji linieritas konflik peran ganda dengan stres kerja sebesar 0,056 dan dukungan sosial dengan stres kerja sebesar 0,166 dengan $p>0,05$, maka asumsi linieritas dalam penelitian ini terpenuhi.

Untuk menguji hipotesis menggunakan analisis regresi ganda metode enter dengan hasil analisis diperoleh nilai $\mathrm{R}=0,633 ; \mathrm{R} 2$ $=0,400 ; \mathrm{F}=39,050 ; \mathrm{p}=0,000(\mathrm{p}<0,05)$, menunjukkan ada hubungan yang signifikan antara konflik peran ganda dan dukungan sosial dengan stres kerja. Hasil tersebut menyatakan bahwa hipotesis adanya hubungan antara konflik peran ganda dan dukungan sosial dengan stres kerja dapat diterima. Nilai koefisien determinasi (R2) $=0,400$ menunjukkan sumbangan efektif konflik peran ganda dan dukungan sosial terhadap stres kerja sebesar 40\% dan sisanya $60 \%$ dipengaruhi variabel lain yang tidak menjadi fokus penelitian ini.

\section{Created with




\section{Diskusi}

Berdasarkan deskripsi data statistik penelitian yang telah dilakukan, stres kerja yang dialami perawat rumah sakit swasta di Yogyakarta pada umumnya berada pada tingkat rendah. Hal ini ditunjukkan dengan nilai rerata empirik stres kerja sebesar 58,9 lebih rendah dibandingkan nilai rerata hipotetik sebesar 62,5. Hal tersebut didukung dengan perolehan nilai rerata empirik konflik peran ganda sebesar 59,9 lebih rendah dibandingkan nilai rerata hipotetik sebesar 60 dan perolehan nilai rerata empirik dukungan sosial sebesar 71,4 lebih tinggi dibandingkan nilai rerata hipotetik sebesar 65.

Hasil penelitian ini juga menunjukkan bahwa ada hubungan yang signifikan antara konflik peran ganda dan dukungan sosial dengan stres kerja pada perawat dengan $\mathrm{R}=0,633 ; \mathrm{R} 2=0,400 ; \mathrm{F}=$ 39,$050 ; p=0,000(p<0,05)$. Hal ini berarti bahwa perawat yang memiliki konflik peran yang tinggi dan dukungan sosial yang rendah, maka tingkat stres kerja yang dialami perawat tinggi. Sedangkan perawat yang memiliki konflik peran ganda yang rendah dan dukungan sosial yang tinggi, maka tingkat stres kerja yang dialami perawat rendah.

Hasil penelitian tersebut didukung penelitian oleh Lambert, Hogan, dan Bartosan (2004) menemukan bahwa terdapat hubungan positif dan signifikan antara konflik peran ganda dengan stres kerja.

Selanjutnya Etzion (1984) dalam penelitiannya mengemukakan stres dalam pekerjaan berkorelasi secara signifikan dengan dukungan dalam pekerjaan.

Hasil penelitian ini juga sesuai penelitian Adams, dkk. (1996) bahwa manfaat dukungan sosial memiliki efek secara langsung pada stresor, bahwa dukungan dan stres berhubungan negatif.

Menurut Sheridan dan Radmacher (1992) serta Gibson, dkk. (1994), stres kerja dipengaruhi oleh kondisi organisasi, seperti penetapan arah dan kebijaksanaan organisasi, perubahan strategi organisasi, dan keuangan, tuntutan kerja, tanggung jawab atas orang lain, perubahan waktu kerja, hubungan yang kurang baik antar kelompok kerja dan konflik peran. Akibatnya konsentrasi kerja terganggu, kinerja kurang memuaskan dan individu tidak dapat memenuhi tuntutan pekerjaannya karena kurangnya dukungan sosial (Luthans, 1998). 
Peran ganda yang diemban oleh wanita ini sangat riskan dengan konflik keluarga-pekerjaan. Konflik dalam keluarga sangat berpengaruh dengan perilaku kerja dan kinerja seseorang (Sastrohadiwiryo, 2003). Konflik-konflik tersebut akan menghambat proses pelaksanaan suatu pekerjaan. Apalagi pada wanita yang bekerja, karena konflik yang dihadapi dapat menyebabkan seseorang tidak dapat berfungsi secara normal dan menjadi tidak seimbang (Mansfield, dkk., 1991).

Selain itu, pada penelitian yang dilakukan oleh Nasir dan Nusi (2001) menemukan bahwa terdapat konflik kerja dan rumah tangga. Konflik dalam keluarga tidak akan terjadi, bilamana adanya keseimbangan antara peran dalam keluarga dengan pekerjaan. Seorang karyawati yang telah berkeluarga memiliki peran ganda, selain berperan sebagai istri dan ibu, ia juga berperan sebagai pencari nafkah. Peran ganda ini sangat riskan dengan konflik, sebab pada umumnya wanita cenderung memprioritaskan keluarganya (suami dan anak) ketimbang pekerjaan. Hal ini dapat menghambat proses pelaksanaan pencapaian kinerjanya. Konflik peran ganda yang mereka alami merupakan faktor pemicu stres kerja.

Hal tersebut sesuai hasil penelitian Cinnamon dan Rich (2002) menunjukkan wanita yang bekerja ternyata lebih sering mengalami konflik dan permasalahan serta lebih menekankan pentingnya permasalahan keluarga dibanding pekerjaan, ketika keluarga sebagai domain yang paling penting bagi kebanyakan wanita. Permasalahan ini dapat mempengaruhi pekerjaan dan dapat menjadi gangguan bagi mereka, sehingga menyebabkan penurunan kinerja.

Konflik peran ganda pada wanita menurut Sekaran (1986) ada enam aspek harus dipertimbangkan, yaitu pengasuhan anak, bantuan pekerjaan rumah tangga, komunikasi dan interaksi dengan keluarga, waktu untuk keluarga, menentukan prioritas (pekerjaan atau keluarga), tekanan karir dan tekanan keluarga.

Hal ini jika tidak ditindaklanjuti akan mengakibatkan seorang wanita yang bekerja akan mengalami stres, seperti gangguan fisiologis, gangguan psikologis, dan gangguan perilaku (Robbins, 2004). Mengingat akibatnya stres dapat mempengaruhi kinerja individu, maka diperlukan suatu upaya untuk mengatasinya. Oleh sebab itu, wanita yang bekerja membutuhkan dukungan sosial untuk mengatasi konflik peran gandanya dan mampu menahan efek stres (Greenglass, dkk., 1989; Kồasa, 1982). 
Menurut Cohen dan Syme (1985), dukungan sosial yang dirasakan akan berfungsi mengurangi efek-efek negatif dari gangguan dan mengembalikan individu kekeadaan kesehatan mental yang baik. Adanya dukungan sosial yang terus-menerus dari lingkungan terdekatnya, dalam hal ini keluarga inti, keluarga besar, rekan kerja dan atasan akan membuat seorang karyawan merasa dihargai dan diperhatikan sehingga konflik yang timbul akan dihadapi dengan tenang.

Fenomena yang terjadi dikarenakan pada organisasi rumah sakit umumnya perawat merupakan bagian yang memegang peranan yang sangat penting karena bagian keperawatan memberikan pelayanan secara purna waktu 24 jam. Di sisi lain, perawat juga dituntut selalu siap dan siaga selama melaksanakan pelayanan, selain itu mereka juga harus memeriksa secara berkala dan secara terusmenerus perkembangan kesehatan pesien selama dalam perawatan.

Hasil penelitian tersebut diperkuat dengan penelitian yang dilakukan oleh Kinnuenens dan Mauno (1998) terhadap 501 pekerja di Filiphina yang menemukan bahwa konflik di tempat kerja dapat mempengaruhi kehidupan di rumah tangga dan sebaliknya konflik di dalam rumah tangga dapat mengganggu pelaksanaan pekerjaan.

Selanjutnya La Rocco, dkk. (dalam Sarafino, 1990) dalam penelitiannya pada 2000 pekerja white and blue-collar menunjukkan hasil bahwa pekerja mendapatkan dukungan emosi dan dukungan instrumental dari supervisor, rekan kerja, keluarga memiliki ketegangan psikologis yang lebih rentan daripada pekerja yang tidak mendapatkan dukungan sosial.

Menurut Greenglass, Fiksenbaum, dan Eaton (2006), dukungan suami merupakan kemampuan suami untuk membantu istri berupa informasi, nasehat, atau sesuatu yang dapat membesarkan hati agar wanita tersebut lebih aktif untuk menyelesaikan masalah yang dihadapi.

Sebagaimana yang dikemukakan oleh Roskies dan Lazarus (dalam Etzion, 1984), atasan yang suportif dapat membuat situasi pekerjaan kurang menimbulkan stres. Dukungan dari atasan antara lain adalah mau mendengarkan masalah yang dialami dengan penuh perhatian, baik masalah pribadi maupun pekerjaan, toleransi terhadap kesalahan yang dibuat dan memberikan kepercayaan pada pekerja bahwa dirinya mampu, sehingga kondisi keriaprang menekan dapat 
terkurangi. Penelitian yang dilakukan French (dalam Katz \& Kahn, 1978) menemukan bahwa dukungan sosial dari teman, supervisor dan bawahan menurunkan efek-efek dari stres kerja.

Dukunganyangdiberikanberupaperhatianemosi,instrumental, informasi dan penilaian (Johnson \& Johnson, 2000). Dukungan yang diberikan dapat mengurangi efek-efek dari stres yang merugikan. Di samping itu, dukungan sosial dari rekan kerja mampu menciptakan rasa nyaman dan ketenangan dalam bekerja, sehingga seseorang yang mendapatkan dukungan dapat menfokuskan perhatiannya pada pekerjaan ketika melaksanakan suatu pekerjaan (Rook, 1987). Rekan kerja yang mendukung menciptakan situasi tolong-menolong, bersahabat dan bekerja sama akan menciptakan lingkungan kerja yang menyenangkan serta menimbulkan kepuasan dalam bekerja (Hadipranata, 1999).

Hal senada juga diungkapkan oleh Qamari (2007), salah satu strategi yang dapat diterapkan oleh para wanita yang bekerja adalah dukungan sosial, dimana memelihara hubungan baik dengan rekanrekan di sekeliling serta atasan, sangatlah penting untuk mencegah timbulnya masalah yang tidak perlu. Dukungan moril dan emosional dari rekan-rekan dan atasan, dapat membuat anda lebih bersemangat kerja. Keberadaan mereka juga dapat berperan dalam membantu saat menghadapi masalah keluarga. Pengertian dan perhatian mereka mampu membuat perasaan yang nyaman saat harus meninggalkan kantor atau menunda pekerjaan karena masalah-masalah berat dan penting di keluarga. Keberadaan rekan-rekan akan membantu dalam mendelegasikan beberapa pekerjaan.

Dukungan sosial di tempat kerja dapat memberikan suatu kontribusi, terutama produktivitas dan kesejahteraan karyawan (Hodson, 1997). Ganster, dkk. (1986) mengatakan dukungan sosial rekan kerja berhubungan secara langsung integrasi seseorang pada lingkungan sosial di tempat kerjanya.

Di samping itu dukungan sosial yang berasal dari rekan kerja merupakan faktor internal organisasi yang akan membantu karyawan keluar dari permasalahan yang dihadapi, apalgi permasalahan tersebut berhubungan dengan pekerjaan. Sebab dukungan sosial rekan kerja mampu mengurangi tekanan-tekanan yang ada di tempat kerja karena pemahaman mereka terhadap stresor yang ada di tempat kerja. Bentuk duakungath yang diberikan rekan kerja berupa 
dukungan informasi dan dukungan instrumental. Selain rekan kerja dukungan yang ada di tempat kerja adalah dukungan yang berasal dari administrator yang memiliki kontribusi yang sangat besar dalam kelancaran pelaksanaan suatu pekerjaan (Brewer \& Miller, 1996). Goerge, dkk. (1993) mengatakan bahwa dukungan rekan kerja dinilai sebagai jaminan terhadap bantuan yang disediakan organisasi yang sangat dibutuhkan dalam melaksanakan suatu pekerjaan secara efektif dan untuk mengatasi situasi yang menekan.

Selain itu, dukungan sosial menurut Johnson dan Johnson (2000) dapat meningkatkan a) Produktivitas melalui peningkatan motivasi, kualitas penalaran, kepuasan kerja dan mengurangi dampak stres kerja, b) Kesejahteraan psikologis dan kemampuan penyesuaian diri melalui perasaan melalui, kejelasan identitas diri, peningkatan harga diri, pencegahan neurotisme dan psikopatologi, pengurangan distres, dan penyediaan sumber yang dibutuhkan, c) Kebutuhan fisik, individu yang mempunyai hubungan dekat dengan orang lain jarang terkena penyakit dan lebih cepat sembuh jika terkena penyakit dibandingkan dengan individu yang terisolasi, d) Manajemen stres yang produktif melalui perhatian, informasi dan umpan balik yang diperlukan untuk melakukan penanganan terhadap stres.

Pada penelitian ini juga menemukan sumbangan efektif konflik peran ganda dan dukungan sosial terhadap stres kerja sebesar $40 \%$ dan sisanya $60 \%$ dipengaruhi oleh variabel lain yang tidak menjadi fokus penelitian ini. Variabel lain yang dapat mempengaruhi munculnya stres kerja, misalnya kondisi fisik, tipe kepribadian tertentu seperti locus of control dan gaya hidup (Dipboye, Smith, \& Howell, 1994) serta harga diri (Dipboye, dkk.,1994; Gibson, dkk., 1994; Riggio, 1996).

\section{Kesimpulan}

Berdasarkan penelitian yang telah dilakukan dan hasil uji hipotesis maka dapat ditarik kesimpulan, sebagai berikut:

1. Stres kerja dan konflik peran ganda yang dialami perawat salah satu rumah sakit swasta di Yogyakarta pada umumnya berada pada tingkat rendah yang ditunjukkan dengan rerata empirik lebih kecil dari rerata hipotetik.

2. Ada hubungan yang signifikan antara konflik peran ganda dan dukungan sosial dengan strestkerja pada perawat. 
3. Semakin tinggi konflik peran ganda dan semakin rendah dukungan sosial maka semakin tinggi stres kerja yang dialami perawat. Sebaliknya, semakin rendah konflik peran ganda dan semakin tinggi dukungan sosial maka semakin rendah stres kerja yang dialami perawat.

Peneliti mengajukan sejumlah saran sehubungan dengan hasil penelitian dan pembahasan yang telah dilakukan. Saran ditujukan kepada perawat dan suami, yaitu:

1. Perawat

Sebagai seorang wanita yang ingin menjalankan karir tetap menjaga keseimbangan peran gandanya yaitu antara pekerjaan dan rumah tangga agar harapannya kedua peran tersebut dapat dijalankan dengan sama baiknya.

2. Suami

Tetap memberi dukungan berupa dukungan moril dan emosional, serta siap membantu pekerjaan rumah tangga agar kedua peran yang dijalankan oleh perawat dapat dijalankan dengan sama baiknya.

\section{Daftar Pustaka}

Adams, G. A., King, L. A., \& King, D.W. (1996). Relationship of job and family involvement, family social support and work-family conflict with job and life satisfaction. Journal of Applied Psychology, 81, 411-420.

Anaroga, P. (1992). Psikologi kerja. Jakarta: PT. Rineka Cipta.

Asih, Y. (1995). Panduan relaksasi dan reduksi stres. Jakarta: Penerbit Buku Kedokteran, EGC.

Azwar, S. (2007). Penyusunan skala psikologi. Yogyakarta: Pustaka Pelajar.

Beehr, T. A. (1985). Psychological stress in the workplace. London: Routledge.

Beehr, T. A., \& Newman, J. E. (1988). Psychological stress in the workplace. London: Routledge.

Beutell, N. J. \& Greenhauss, J. H. (1983). Integration of home and non home roles: Women's conflict and coping behavior. Journal of Applied Psychology, 68, 43-48.

Beutell, N. J. \& Greenhauss, J. H. (1985). Sources of conflict between work

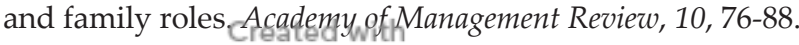

Brewer, M. B., \& Miller, N. (1096). Intergroup relatists Buckingham: Open 
University Press Celtic Court.

Broadbridge, A., Swarson, V., \& Taylor, C. (1999). The implications of retail changes on employees' job demands, satisfactions, and the work/ home interface. Institute for Retail Studies.

Budiman. (2006). Persepsi efektivitas kinerja karyawan ditinjau dari konflik peran ganda isteri dan dukungan sosial rekan kerja. Tesis (tidak diterbitkan). Yogyakarta: Fakultas Psikologi Universitas Gadjah Mada.

Cinnamon, R. G., \& Rich, Y. (2002). Gender differences in the importance of work and family roles: Implications for work-family conflict. Sex Roles: A Journal of Research, 47, 531-541.

Cohen, S., \& Syme, S. L. (1985). Social support and health. Florida: Academic Press. Inc.

Dalton, J. H., Elias, M. J., \& Wardersman, A. (2001). Community psychology, lingking individuals and communities. Balmont: Wadworth/Thomson Learning.

Dipboye, R. L., Smith, C.S., \& Howell, W. C. (1994). Understanding an industrial integrated organizational approach psychology. Florida: Hacourt Brace.

Duxbury, L. E., \& Higgins, C. A. (1991). Gender differences in work family conflict. Journal of Applied Psychology, 76, 60-74.

Etzion, D. (1984). Moderating effect of social support on the stress-burnout relationship. Journal of Applied Psychology, 69, 615-622.

Evan, G. W., \& Johnson, D. (2000). Stress and open office noise. Journal of Applied Psychology, 85, 779-783.

Fitria, Y. (2006). Penilaian positif terhadap pekerjaan: Studi eksplorasi bertahannya perawat pada pekerjaan.

Fontana, D. (1993). Managing stress. UK: Psychological Society and Routledge, Ltd.

French, J. R. P., Chaplan, R. D., \& Harrison, R. V. (1982). The mechanism of job and strain. Chichester, England:Wiley.

Freser, T. M. (1986). Stres dan kepuasan kerja (terjemahan). Jakarta: Pustaka Binaman Pressindo.

Ganster, D. R., Fusilier, M. R., \& Mayes, B. T. (1986). Role of social support in the experient of stress at work. Journal of Applied Psychology, 69 (2), 102-110.

Gelles, R. J. (1995). Contemporary families: A sociological view. London: Sage Publications.

Gibson, J. L., Ivancevich, J. M., \& Donnely, J. H. (1994). Organizations: Behavior, structure, processescDallas: Rithard D. Irwin, Inc. 
Gifford, R. (1987). Environmental psychology: Principles and practice. Massachusetts: Ally and Bacon, Inc.

Goerge, J. M., Reed, T. F., Ballard, K. A., Colin, J., \& Fielding, J. (1993). Contact with AIDS patients as a source of work-related distress. Effect of organizational and social support. Academy of Management Journal, 36 (15), 17-71.

Greenglass, E. R., Pantony, K. L, \& Burke, R. J. (1989). A gender role perspective on role conflict, work stress and social support in Goldsmith, E. B. work and family: Theory, research and aplications. London: Sage Publications.

Greenglass, E. R., Fiksenbaum, L., \& Eaton, J. (2006). The relationship between coping, social support, funtional disability and depression in the elderly. Journal Routlegde Taylor and Francis Group, 1, 15-31.

Gunarsa, S. D., \& Gunarsa, Y. S. D. (1995). Psikologi keperawatan. Jakarta: BPK Gunung Muria.

Hadipranata, F. A. (1999). Mikeo bukan MBO. Buletin Psikologi, Tahun IV, No. 1, Agustus 1996, 1-5. Yogyakarta: Fakultas Psikologi Universitas Gadjah Mada.

Hodson, R. (1997). Group relations at work splidarity, conflict and relations with management work and occupation. Journal of Applied Psychology, 24, 426-452.

Johnson, D. W., \& Johnson, F. P. (2000). Joining together: Group theory and group skill (7th. Ed.). New Jersey: Prentise Hall.

Katz, D., \& Kahn, R. L. (1978). The social psychology of organization (2 ${ }^{\text {nd. }}$ ed.). New York: John Willey and Sons.

Kinnuenens, U., \& Mauno, S. (1998). Antecendent and outcome of work family, conflict among employee women and men in Finland. Journal Human Relation, 51, 157-177.

Kobasa, S. C. (1982). Hardiness \& health: A prospective study. Journal of Personality \& Social Psychology, 42, 168-177.

Lambert, E. G., Hogan, N. L., \& Bartosan, S. M. (2004). The nature of family conflict among correlation staff: An explanatory examination. Criminal Justice Review, 16 (1), 145-172.

Lazarus, R. S. (1991). Emotional and adaptation. New York: McGraw-Hill Publishing Company.

Lemme, B. H. (1995). Development in adulthood. Boston: Allyn \& Bacon, Ltd.

Luthans, F. (1998). Organizational behavior. Singapore: McGraw-Hill Books Company.

Mansfield, P. K., Koch, P. B., Henderson, J., Vicary, J. R., Cohen, M., \& Young, E. W. (1991). The job climate for women in traditionally male blue collar occupations. Journal of Sex Role, 25, 63-79.

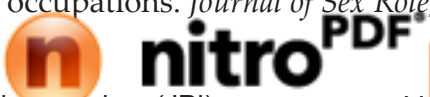

PSIKOISLAMIKA, Jurnal Psikoivyr Islam (JPI) 
Miner. (1992). Industrial organizational psychology. New York: McGraw-Hill. Inc.

Napoli, V., Kilbride, J. M., \& Tebs, D. E. (1988). Adjustment and growth in a changing world. Minnessota: West Publishing Company.

Nasir, R., \& Nusi, N. E. (2001). Tekanan kerja, tekanan rumah tangga dan komitmen kerja dikalangan pegawai dan anggota wanita polis Diraja Malaysia (PDRM). Jurnal Psikologi Malaysia, 15, 21-37.

Newsom, J. T., \& Schultz, R. (1996). Social support as a mediator in the relation between functional status and quality of life in older adults. Psychology and Aging, 11 (1), 34-44.

Norris, F. H., \& Kaniasty, K. (1996). Received and perceived social support in time of stress: A test of the social deterioration difference of model. Journal of Personality and Social Support, 71 (3), 498-511.

Parasuraman, S., Greenhauss, J. H., \& Granrose, C. S. (1992). Role stressors, social support, and well-being among two-career couples. Journal of Organizational Behaviour, 13, 339-356.

Pestonjee, D. M (1992). Stress and coping: The Indian experience. New Delhi: Sage Publications, Ltd.

Pratopo, T. C. (2001). Hubungan antara motivasi dengan stres kerja pada perawat RS. PKU Muhamadiyah Yogyakarta. Skripsi (tidak diterbitkan). Yogyakarta: Fakultas Psikologi Universitas Wangsa Manggala.

Qamari, I, N. (2007). Peran dukungan suami dalam memoderasi pengaruh tuntutan waktu peran kerja terhadap konflik peran ganda pada karyawati bank. Jurnal Pusat Studi Wanita, 1, (10). Yogyakarta: Universitas Muhammadiyah.

Quick, J. C., \& Quick, J. D. (1984). Organizational stress and preventive management. New York: McGraw-Hill.

Riggio, E. R. (1996). Introduction to industrial organizational psychology. New York: Harper Collins Collage Publisher.

Riggio, E. R. (2003). Introduction to industrial organizational psychology. New York: Harper Collins Collage Publisher.

Robbins, S. P. (2004). Teori organisasi, struktur, desain, dan aplikasi. (Alih Bahasa: Tim Indeks). New Jersey: Prentice Hall.

Rook, K. (1987). Social support versus companionship: Effects on life stress, loneliness, and evaluations by others. Journal of Personality and Social Psychology. 52 (6), 1132-1147.

Sarafino, E. P. (1990). Health Psychology: Biopsychosocial Interactions. New York: John Willey \& Sons, Inc. 
Sastrohadiwiryo, B. S. (2003). Manajemen tenaga kerja Indonesia pendekatan administratif dan operasional. Jakarta: Bumi Aksara.

Sekaran, U. (1986). Dual career families. San Fransisco: Josey Bass Publishers.

Sheridan, C. L., \& Radmacher, S. A. (1992). Health psychology: Challenging the biomedical model. Singapore: John Wiley and Sons, Inc.

Schultz, D. P. (1982). Psychology and industry today: An introduction to industrial and organizational psychology. New York: McMillan Publishing Company, Inc.

Schultz, D. P., \& Schultz, S. E. (1994). Psychology and work today. New York: McMillan Publishing Company, Inc.

Suryanita, Y. (2001). Hubungan antara strategi penanggulangan stres sindrom burnout pada perawat di Kota X. Jurnal Psikologi Fakultas Psikologi Universitas Widya Mandala, 1 (1), 20-44.

Tellenback, S., Breuner, Sten-Olof, \& Lofgren, H. (1983). Teacher stress: Exploratory model building. Journal of Occupational Psychology, 57 (1), 277-293.

Thoits. (1986). Social support as coping assistance. Journal of Consulting and Clinical Psychology, 54, 416-423.

Voydanoff, P. (1988). Work role characteristics, family structure demands, and work-family conflict. Journal of Marriage and the Family, 50, 749-761.

Voydanoff, P. (1995). The work and family interface: Toward a contextual effects perspective. Minneapolis: National Council on Family Relations.

(http://id.wikipedia.org/wiki/perawat)

\section{Created with}

